\title{
Herbert Yee and Ian Storey (eds.), The China Threat: Perceptions, Myths and Reality
}

London, New York, RoutledgeCurzon, 2002, 338 p.

Jean-Pierre Cabestan

\section{OpenEdition}

\section{Journals}

Édition électronique

URL : http://journals.openedition.org/chinaperspectives/421

DOI : 10.4000/chinaperspectives.421

ISSN : 1996-4617

\section{Éditeur}

Centre d'étude français sur la Chine contemporaine

Édition imprimée

Date de publication : 1 octobre 2004

ISSN : 2070-3449

\section{Référence électronique}

Jean-Pierre Cabestan, « Herbert Yee and Ian Storey (eds.), The China Threat: Perceptions, Myths and Reality ", China Perspectives [En ligne], 55 | september - october 2004, mis en ligne le 28 novembre 2006, consulté le 21 septembre 2020. URL : http://journals.openedition.org/chinaperspectives/421 ; DOI : https://doi.org/10.4000/chinaperspectives.421

Ce document a été généré automatiquement le 21 septembre 2020.

(C) All rights reserved 


\title{
Herbert Yee and Ian Storey (eds.), The China Threat: Perceptions, Myths and Reality
}

London, New York, RoutledgeCurzon, 2002, 338 p.

\author{
Jean-Pierre Cabestan
}

\section{NOTE DE L'ÉDITEUR}

Translated from the French original by Philip Liddell

1 This book brings together 16 essays on the outside world's changing perception of the People's Republic of China (PRC), in the period since Tiananmen and, later, following the missile crisis in the Taiwan Strait (1995-1996). The essays are based on contributions to a conference in January 2001 in Hong Kong; thus, having been completed before September 11th 2001, the book might be assumed dated. In fact, it is not. For while the outbreak of Islamic terrorism and the Iraq War have put into wider perspective the reality and the imminence of the Chinese threat, this book shows that some countries, especially those in China's immediate neighbourhood (such as Japan, South-East Asia and Russia), will continue to perceive the threat as continuing, even acute. It also shows that China's growing power is above all regional and affects much the other areas of the world, in spite of an increasing influence on the international energy, raw material and food markets.

2 The contributors to this study (with the exception of Edward Friedman in his chapter on Taiwan) see the Chinese threat as more potential than real. In fact, China's persistent weaknesses are rightly emphasised : the problems of its state industries, the fragility of its banking system, the backwardness of its agriculture, the demographic pressure and the growing social tensions. Even so, as this book shows, a further series of factors has encouraged the emergence of a "Chinese threat", that is to say, round about 1993, "the PRC as a rising power represents a source of regional and 
international instability" (p. 2). Of these factors, Herbert Yee and Ian Storey headline five : the rapid development of the Chinese economy between 1978 and 1992 (growth averaging $9.9 \%$ per year) ; the authoritarian political system ; China's growing military strength accompanied by intensified territorial disputes with some neighbours (the South China Sea) and the confrontation with Taiwan; conversely, the Chinese government's fear of a political and economic collapse ; and lastly the rise of Chinese nationalism and especially of anti-American feeling.

On reading various chapters of the book, it seems to be the third and the fifth of those factors that have most effectively crystallised the concept of a Chinese threat. As Yee and Storey show in the chapter devoted to Chinese criticism of this idea, it was during the missile crisis in the Taiwan Strait that articles denouncing the existence of a Chinese threat became particularly numerous (p. 22). Similarly, the modernisation of the People's Liberation Army, without directly challenging the supremacy of the American military, makes China "the most credible prospective rival of the United States in the decades to come", especially in the two theatres where the two countries find themselves most closely engaged, namely, the Korean Peninsular and Taiwan (Jonathan Pollack). For Japan, the Chinese threat is closely linked to developments in Taiwan. But, as Wenran Jiang points out, it also has further complexities arising from the two powers' rivalry for influence in East Asia, particularly in South-East Asia, and from Japanese anxieties about whether the People's Republic might become unstable from within-a major preoccupation in Tokyo since Tiananmen. As for the countries of South-East Asia, although all are sensitive to the growing tension in the Taiwan Strait, their attitude to China has turned out more complex and more ambiguous because of the presence of significant Chinese communities in most of them (Singapore, Malaysia, Indonesia, Thailand and the Philippines) and the territorial disputes that they have with Peking in the South China Sea. The case of the Philippines is well set out by Aileen San Pablo-Baviera; she outlines China's strategy of establishing a fait accompli in the area of the Spratly Islands (Mischief Reef) in 1995 ; and she shows how this encouraged the perception of a Chinese threat. Vietnam, despite its difficulties with China (as Carlyle Thayer shows), chose a different strategy, improving its links with Peking while at the same time diversifying its relations with the rest of the world. But for 2,000 years its aim has never altered : attempting to contain the oppressive power of its northern neighbour. Lastly, in the case of India, it is the threat of China's nuclear weapons that has justified Delhi's nuclear ambitions.

4 There are other countries and regions that do not perceive any threat from China. That is true not only of Pakistan, a long-term ally of China, and the Middle East, where (according to Yitzhak Shichor) Chinese weapons accounted for no more than 5\% of arms imports between 1983 and 1997, but also of Russia, where (Alexander Lukin reports) only a minority see Chinese immigration as a threat to the stability of Russia's Far East territories. Lastly, in the European Union (as Joachim Glaubitz shows), the Chinese threat is perceived as much in terms of human rights and the environment as of the Taiwan problem.

5 What the various contributions reveal, without always admitting it or clearly setting it down, are the direct connections, firstly between these varying perceptions and the Chinese government's foreign policy, and secondly between this foreign policy and Peking's domestic concerns. After Tiananmen, Peking embarked on an anti-Western policy in order to avoid any "peaceful evolution" towards democracy. Then, the 
collapse of the Soviet Union forced the Chinese Communist Party (CCP) to find a substitute for the building of socialism. It was then that Deng Xiaoping relaunched the reforms and promised "wealth and power" to the Chinese people. To mobilise society behind these aims, the Chinese authorities gave full rein to the nationalism that they had been repressing during the 1980s and increased their pressure on Taiwan, feigning the desire to accelerate the return of the island to China. At the same time, they redoubled their armed forays in the Spratlys. More generally-and this point is missing from the book-the CCP leadership spread the idea, within Chinese society and also abroad, that their country could swiftly match up to the world's leading powers, and especially the United States, both economically and militarily. In other words, in the course of the 1990s, China was tempted to put itself on a collision course with America and its allies, in the Asia-Pacific region and elsewhere. That is the real origin of the "Chinese threat" syndrome.

What is more, China is well aware of it. Since George W Bush was elected, and since September 11th 2001, Peking has sought by highly visible gestures to defuse this perception, taking on board (yet without acknowledging it) the advice of some Chinese academics settled overseas, such as Wu Guoguang and Zheng Yongnian-advice that is recalled in the book at the end of Chapter 1 . Thus, Chinese leaders began to show a more evident interest in multilateralism, the peaceful resolution of disputes and the search for a more realistic modus vivendi (that is to say, taking existing alliances into account) with the United States. That is also the origin of the "Peaceful Rise" theory enunciated at the end of 2003 by Hu Jintao's adviser Zheng Bijian but hurriedly put under wraps (at least until Jiang Zemin's retirement in September 2004) because of the divisions it aroused within the communist leadership.

7 So the main reservation that one might have about this book is that it gives little emphasis to the connection between, on the one hand, people's perceptions-often pertinently and precisely analysed-and, on the other, China's real intentions. While China's true aims cannot yet be realised, they do explain in large part the anxieties felt abroad. They are not all military, except where Taiwan is concerned. But China's political and diplomatic ambitions, supported by a dynamic economy, are bound to affect-and, to some extent, destabilise-the surrounding region, notably Japan, the Korean Peninsula and South-East Asia. And one cannot merely bet on the possibility that, by the time China has assembled the means to encompass its ends, it will have dropped its more threatening objectives thanks to the policy of integration and engagement favoured by nearly all governments. Most capitals in the Asia-Pacific Region look beyond that gamble, playing for a balance between Peking and Washington that is obviously required to continue. 